\title{
"YESTERDAY'S MILITARY SHOW": AN UNCOLLECTED PIECE OF WHITMAN JOURNALISM
}

\author{
MARTIN G. MURRAY
}

MORE THAN A CENTURY after its first publication, an unknown piece of Walt Whitman's Washington, D.C., journalism has been found and may now be added to his collected writings. ${ }^{1}$ The latest addition is "Yesterday's Military Show," a signed contribution that appeared in the Wednesday, September 13, 1871, edition of The Daily Morning Chronicle. Appearing on page one, column five, the article recaps several local processions marking the anniversary of an important battle in the War of 1812 and marking the rebirth of several local militias. While Whitman expresses delight in such civic celebrations, his article also conveys ambiguity concerning a resurgent militarism: Whitman's respect for the duty-driven citizen soldier is coupled with regret over man's violent nature that seems inevitably drawn to war.

Here is the article:

Yesterday's Military Show.

Although it was not by any means a general military turn-out, the parade of yesterday, with its plentiful bands of music, was animating and creditable enough to call for special notice. The day was the anniversary of the battle of North Point. Most of our readers will not have much idea what that was, for mighty events have since intervened. But a sprinkling of old fellows who either knew all about it, or took part in it, still remain, and it was well to mark the day. Then, as it has turned out, yesterday creates quite an era in our local military history, and will affect the future. The soldiering spirit which was general before the war had spent itself so thoroughly in the bloody bayonet charges and real cannon balls of that contest, that it has rested and slept pretty quietly since. But the male human creature is shown by history to be, upon the whole, a warlike animal. And, according to yesterday's exhibition, partial as it was, the military rage has only been sleeping, to now break forth again. Heaven grant it may ever continue, as at present, merely for preparation, and for healthy exercise, gratification, and development.

The sound of drums and trumpets began early in the forenoon. The Baltimore Veterans of 1812, having arrived between 10 and 11 o'clock, were comfortably marched about with music and banners, and 
duly dined by our Washington veterans. They did not march a great deal, however, but took the cars, like prudent veterans as they were. They looked like first-rate old chaps.

About 3 o'clock the battalion parade of Washington Light Infantry, in their white pants and dark coats, came off, and was universally considered a success. Nothing could be better than their carriage and step, and nothing more lively than their passage up Pennsylvania avenue to the superb strains of the Marine Band, who were in force, and made a gay contrast to the rest in their scarlet coats. The infantry-some 250 or 300 in number - were preceded by the new horse troop-the President's Guard-got up the past summer under Colonel Owen. Though only numbering thirty five or forty, they produced a fine effect.

A little after 4 o'clock there was a funeral, under the auspices of a well-dressed association of working men, who marched in procession, headed by a small but good band playing the Dead March from Gazza Ladra.

About 7 o'clock in the evening the National Guard, company B, in their appropriate and manly uniforms of gray, marched down the Avenue, preceded by a separate squad of the Marine Band, playing a stirring air. Though this company was small their appearance was greatly commended.

Altogether Washington has reason to be satisfied with yesterday. The old chaps carried off some of the honors; still we think that upon the whole, the more youthful Washington deserves the palm. "God bless those young men!" ejaculated a pleased and pious elderly citizen on the curbstone as the closing ranks of the Light Infantry passed by, with firm, light, regular step; "God bless their handsome faces!" We overheard the enthusiastic deacon, and will conclude by giving and sincerely joining in his devout wishes.

WALT WHITMAN.

Whitman's commentary was supplemented by more extensive reports of the day's activities elsewhere in the Chronicle, as well as in the Evening Star. These provide a useful context in which to read and appreciate Whitman's journalism.

September 12, 1871, was the fifty-seventh anniversary of the War of 1812's Battle of North Point, Maryland, which probably had greater resonance for the citizens of Washington and Baltimore than Whitman acknowledges. This battle had followed upon the British sacking of the nation's capital in the summer of 1814, and came as the enemy trained its sights on neighboring Baltimore. The advance, however, was slowed at North Point when a skirmish with the hastily summoned citizen soldiery resulted in the death of British Commanding General Robert Ross. This was followed by the Americans' successful defense of Fort McHenry against His Majesty's Navy, famously giving rise to the "Star-Spangled Banner," written by Georgetown attorney Francis Scott Key. 
The observance of the anniversary began in D.C. with a one-hundred-gun salute at the Armory, after which the Washington veterans greeted the arrival of their Baltimore brethren at the Baltimore and Ohio Railroad depot. Whitman observes that the veterans didn't march but rode the city's horse-drawn railway to various points in the city; the cars were specially provided by the Metropolitan Railroad and took the veterans to the White House and Capitol, then onto their luncheon banquet at Shaffer \& Benser's oyster saloon on Sixth Street, NW, and finally back to the rail depot for their return to Baltimore. ${ }^{2}$

The day's principal parade featured the Washington Light Infantry, escorted by the President's Mounted Guard. As Whitman observes, both militias had long histories in the city (the former was founded in 1836 and the latter in 1853); however, after brief service guarding the capital at the opening of the Civil War, the units were discharged to enable their members to join more active Union regiments and were not reconstituted until $1871 .^{3}$ Thus, the parade was their first joint public show in many years. Whitman remarked upon the soldier's youthful comeliness and their gaily-colored uniforms. Other news reports also took note of the blue Derby coats, white canvas pantaloons, black hats, and white belts of the Light Infantry, and the Mounted Guard's blue uniforms with gold cord for officers and yellow edging for privates, shoulder knots, and smart caps topped off with white pom-poms.

The parade commenced at City Hall (D and $4 \frac{1}{2}$ streets, NW), and its circuitous route (first east along Pennsylvania Avenue to the Capitol, then west again toward the White House, and north on $15^{\text {th }}$ Street, to return again to the starting point), brought it directly past the residence on M Street, NW, near $12^{\text {th }}$, where Whitman is believed to have lived at this time. ${ }^{4}$ The Evening Star reported that "on M Street, they [the marchers] received a perfect ovation, the pavements being crowded with ladies and children, while from many windows flags were displayed and handkerchiefs waved." $"$ The Marine Band serenaded the infantrymen; the musicians were favorites of Whitman who, in company with his friend Pete Doyle, regularly attended their concerts on the White House lawn. ${ }^{6}$

In the midst of these civil displays, Whitman stopped to observe a funeral procession. ${ }^{7} \mathrm{He}$ was particularly struck by the accompanying band's rendition of the "Dead March" from Rossini's La Gazza Ladra [The Thieving Magpie], an opera that was one of the poet's "special enjoyments." 8

Whitman rounded out the day by observing still another parade, by the National Guard (formerly the Washington Light Guard), which was also escorted by the Marine Band. This march took place in the city's Capitol Hill neighborhood, along Pennsylvania Avenue and $8^{\text {th }}$ Street, SE, near the guard's headquarters at the Odd Fellows' Hall by the Navy Yard. 
"Yesterday's Military Show" appeared in The Daily Morning Chronicle, edited by John M. Morris and William W. Holden. The daily was affiliated with the Sunday Morning Chronicle, which was edited and published by Whitman's friend, Colonel John W. Forney. Emory Holloway has previously identified several other pieces of Whitman journalism published in Forney's papers. ${ }^{9}$ Indeed, on Friday, September 8, the Chronicle published "After All, Not to Create Only," which Whitman had presented at the opening of the American Institute's National Industrial Exhibition in New York the previous day, and on Monday, September 11, the Chronicle printed Whitman's (anonymous) laudatory review of his own recitation of the poem at the exhibition.

Although "Yesterday's Military Show" is a fairly straightforward description of the day's activities, it also served as a platform for particular Whitman interests. The honor accorded the old veterans is similar to that Whitman displayed for the Revolutionary War heroes of his Brooklyn boyhood, such as those he saw with Lafayette at the laying of the Apprentice Library cornerstone, ${ }^{10}$ or the Long Island farmer (one of "The Last of the Sacred Army") with whom the young schoolteacher celebrated one Fourth of July, ${ }^{11}$ or those veterans featured in Whitman's poems, "The Dying Veteran" and "The Centenarian's Story." 12

At the same time, the piece voices wariness about the resurrection of the militia. The poet laments the male creature's warlike nature and prays that such military shows might always be "merely for preparation, and for healthy exercise, gratification, and development." Whitman's apprehension was probably reinforced by his chance encounter with the funeral procession. Whitman's article has the only mention of the mourners made in the local papers, and he evidently inserted it in "Yesterday's Military Show" as an oblique reference to war's inevitable casualties. The poet had noted around this time that he associated Rossini's "Dead March," the tune played during the funeral procession, with the Civil War hospitals in which he had heard it performed, and the attendant suffering and death he had witnessed there.$^{13}$ Of the soldiers on parade from the President's Mounted Guard, many had followed their captain, Samuel Owen, into the Third Pennsylvania Cavalry, and in such battles as Antietam, Chancellorsville, Gettysburg, and the Wilderness, they certainly experienced "the bloody bayonet charges and real cannon balls" recalled by Whitman in his newspaper piece. Several of the Washington recruits to this regiment lost their lives in battle or as prisoners of war in the infamous Andersonville prison. ${ }^{14}$

Although this fear of man's belligerent nature was a direct consequence of his Civil War experiences, Whitman had refrained in his published War correspondence and poetry from a blanket condemnation, preferring instead to dignify the war's violence as a necessary means to a valued end. In his American Institute poem, however, Whitman voiced more pacifist sentiments, declaring, "Away with themes of war! away 
with War itself! / Hence from my shuddering sight, to never more return, that show of blacken'd, mutilated corpses!"15 Yet in this piece, the perpetrators of war's violence remained abstract. While "Yesterday's Military Show" lacks the hyperbole of the American Institute sentiments, it is significant that Whitman begins to connect the actors (militiamen) with the act (war). This frightening vision of man's blood lust would reappear more strongly in such writings as "A Glimpse of War's HellScenes" (1875), in which the poet describes successive scenes of Rebel and Union soldiers killing unarmed captives in Upperville, Virginia, in the fall of 1864 . From that specific incident, Whitman draws a sweeping conclusion:

Multiply the above by scores, aye hundreds — varify [sic] it in all the forms that different circumstances, individuals, places, \&c., could afford-light it with every lurid passion, the wolf's, the lion's lapping thirst for blood, the passionate, boiling volcanoes of human revenge for comrades, brothers slain-with the light of burning farms, and heaps of smutting, smouldering black embers-and in the human heart everywhere black, worse embers - and you have an inkling of this War. ${ }^{16}$

Whitman was not prepared to make such an overriding statement in "Yesterday's Military Show," but instead closes on a positive note by recording his own palpable pleasure in the sights and sounds of parading men. Had Whitman not signed this article but rather inserted himself as a character (as was often his wont), we might have expected him to appear as the "pleased and pious elderly citizen," ejaculating blessings upon the young soldiers. Perhaps this curious exchange is Whitman's indirect way of advocating comrade-love as a fitting channel for man's passionate nature and a means to prevent conflict, whatever the prevailing societal stresses.

A personal aside: as I write my own closing paragraph, it would appear that "the warlike animal" identified by Whitman in 1871 still rages. Today, the Washington Post (November 24, 2003) reports that yesterday's military show included five soldiers killed in occupied Afghanistan and another two in occupied Iraq. And a Post report on the uproar over gay marriage indicates that acceptance of Whitman's "love of comrades" is a dream yet deferred. ${ }^{17}$ Ça ira, Whitman might sigh.

\section{The Washington Friends of Walt Whitman}

\section{NOTES}

1 I am indebted to Sherwood Smith and Kurt Vorndran for their helpful comments on a draft of this paper.

2 See "Twelfth of September; How the Day was Celebrated," The Daily Morning Chronicle, Washington, D.C., September 13, 1871, page 4, columns 2 and 3. 
3 For information on the Washington Light Infantry, see "MS 298 Washington Light Infantry Corps Records, 1840-1898," in the collection of The Historical Society of Washington, D.C. For the history of the President's Mounted Guards, see "1812 and 1871; Old Defenders and Young Defenders; Celebrating the Battle of North Point," Evening Star, Washington, D.C., September 12, 1871, page 4, columns 2 and 3.

4 See Kim Roberts, "Walt Whitman," in Beltway: A Poetry Quarterly 4 (Fall 2003), http://www.washingtonart.com/beltway/whitman2.html.

5 “Our Citizen Soldiers," Evening Star, Washington, D.C., September 13, 1871, page 1 , column 7 .

6 Walt Whitman, Calamus: A Series of Letters Written During the Years 1868-1880 by Walt Whitman to a Young Friend (Peter Doyle), ed. Richard Maurice Bucke (Boston: Small, Maynard \& Company, 1897), 27.

7 I have been unable to identify the deceased. However, The Evening Star reported two deaths whose funerals occurred on September 12: one for Mary C. Sessford, a young, unmarried woman who was the daughter of John, a printer, and Susan; and the second for Bartholomew Finn, a forty-year old Irish laborer.

8 Walt Whitman, Prose Works 1892, ed. Floyd Stovall (New York: New York University Press, 1963), 1:20. Rossini's La Gazza Ladra is the tale of a young servant, Ninetta, who is wrongly accused and found guilty of stealing silver cutlery from her employer. By the "Dead March," Whitman is apparently referring to that part of the opera, occurring towards the end of the second and final act, in which the convicted, sentenced to death, is marched through town to the place of her appointed execution. All ends well when it is discovered that the silver was actually stolen by the "thieving magpie" of the title, averting Ninetta's execution and enabling her to marry her beloved, Giannetto. I am indebted to Howard Jaffe, Sound Recordings Cataloguer at the Library of Congress, for his assistance in identifying this piece of music.

9 Emory Holloway, "Whitman as His Own Press Agent," The American Mercury, 18:72 (December 1929), 482-488.

10 Walt Whitman, "Brooklyniana," Brooklyn Standard, June 1861 to November 1862; reproduced in Major Authors on CD-ROM: Walt Whitman, ed. Ed Folsom and Kenneth M. Price (Woodbridge, CT: Primary Source Media, 1998).

11 Walt Whitman, The Early Poems and the Fiction, ed. by Thomas L. Brasher (New York: New York University Press, 1963), 95; reproduced in Major Authors.

12 Walt Whitman, Leaves of Grass: Comprehensive Reader's Edition, ed. Harold W. Blodgett and Sculley Bradley (New York: New York University Press, 1965), 297, 529; reproduced in Major Authors.

13 Walt Whitman, Notebooks and Unpublished Prose Manuscripts, ed. Edward F. Grier (New York: New York University Press, 1984), 2:869; reproduced in Major Authors.

14 Samuel P. Bates, History of Pennsylvania Volunteers, 1861-5 (Harrisburg: B. Singerly, State Printer, 1869), 2:360-368, 381-383. The Washingtonians were recruited into Company D, Sixtieth Regiment-Third Cavalry. Owen was Lt. Colonel of this regiment at its formation.

15 Walt Whitman, Leaves of Grass, A Textual Variorum of the Printed Poems, ed. Sculley Bradley, Harold W. Blodgett, Arthur Golden, and William White (New York: New York University Press, 1980), 3:619; reproduced in Major Authors. 
16 Walt Whitman, Memoranda During the War (Bedford, MA: Applewood Books, 1993), 36; facsimile of 1875 edition.

17 The Washington Post, Monday, November 24, 2003, pages A10 and B1. 